\title{
ECONOMIC EFFICIENCY OF KOREAN LIFE TECHNOLOGY IN FEEDING OF ANIMALS
}

\author{
Tursunov Shavkat Alamovich ${ }^{1}$, Ilmuratov Shavkat Maxsumovich ${ }^{2}$ \\ ${ }^{1}$ Branch of the Federal State Budgetary Educational Institution of Higher Education \\ "Astrakhan State Technical University" in Tashkent, Uzbekistan \\ ${ }^{2}$ Branch of the Federal State Budgetary Educational Institution of Higher Education \\ "Astrakhan State Technical University" in Tashkent, Uzbekistan
}

\begin{abstract}
The aim of the study is to develop theoretical and methodological approaches to optimizing the business processes of a livestock enterprise based on the development of decision support systems for managing the operation of a herd and the production of livestock products, taking into account the relationship between technological processes and economic results, including a set of mathematical models, methods and fodder base, management of animal exploitation.
\end{abstract}

KEYWORDS: Economic efficiency, in feeding animals, Korean TMR technology

\section{INTRODUCTION}

Livestock is the main sector that meets the demand of the population for food products, and in 2019 , livestock products accounted for $49.8 \%$ of the total volume of agricultural production in the country. This sector provides the population with high quality food products and raw materials to many industries. Therefore, it is important to study the state of the industry and show opportunities for further development.

According to the Resolution of the President of the Republic of Uzbekistan dated January 29, 2020 No PP-4576 - "On additional measures of state support of the livestock sector", as well as the uninterrupted supply of the population with quality and affordable livestock products produced locally, as well as government support for enterprises specializing in animal husbandry. Ensuring food security of the country's population is an important and fundamental task. A special place in the implementation of this work belongs to agriculture, which is a priority of the national economy, and the livestock sector, which is an important part of it. This places a huge responsibility on all professionals working in this field.

The development of animal husbandry and the problems in accelerating the production of livestock products are related to the strengthening of the fodder base and the provision of livestock with nutritious food at the required level. Inadequate nutrition is one of the main problems in the development of livestock in Uzbekistan. Lack of land on farms does not allow them to fully feed their livestock.
Nutrition is the most important of all factors in livestock development. Feeding has a strong impact on livestock productivity. The animal's body receives from the animal feed the material necessary for the structure of the tissues, the substances that regulate metabolism, and the energy.

\section{METHODOLOGY}

The theoretical and methodological basis of the dissertation work was the works of leading economists devoted to the issues of improving the economic efficiency of the functioning of the livestock subcomplex in the agro-industrial complex. Legislative and other regulatory documents, materials of state statistical bodies, as well as materials of annual reports and primary accounting of enterprises in the regions of the republic, personal observations of the author, national economists, works of scientists from near and far abroad countries, research in various areas of private animal husbandry, breeding, feeding of cattle. When summarizing and analyzing the initial information, the monographic method, the grouping method, correlation and regression analysis, as well as a number of methods and techniques of economic research were used: economic-statistical, abstract-logical.

\section{RESULTS AND DISCUSSION}

Currently, two methods of feeding animals are used in practice:

1) distribution of each type of feed to animals is carried out separately in a certain sequence with a time interval; 
2) All types of nutrients are distributed to nutrients in the form of a balanced nutrient mixture (in Germany such nutrients are called TMR - Total Mischration, in English-speaking countries Unifeed).

In the implementation of the first method of feeding animals, the preparation for feeding each type of feed separately is carried out using specialized technological lines or separate machines.

The transition from separate distribution of feed to feed mixtures with a predetermined nutritional value will increase the milk yield of cows by $0.9 \mathrm{~kg}$ per day, reducing the consumption of basic feed by $20-30 \%$.

The technology of feeding livestock with mixed feeds (the second method) is superior to all types of fodder, which is due to the uniformity of the digestive process, because with each portion the animals receive a balanced feed mixture.

When feeding livestock, optimal conditions for digestion must be created, because all the nutrients and components that make up the composition of the feed come in equal proportions. Vibrations of the acidic environment $(\mathrm{pH})$ in the stomach are almost non-existent, preventing normal metabolism. In addition to improving the health of the animal, more efficient use of the feed is achieved as a result of its complete consumption. Selective consumption of the most appetizing components is almost not allowed, losses are reduced. In addition, there is an opportunity to include in the diet alternatives that have a high level of nutrition and digestibility, are naturally poorly consumed, as well as the ability to formulate and select the optimal ration of nutrition.

In order to increase the meat productivity and quality of bulls in Uzbekistan using the technology of feeding and fattening of bulls in Uzbekistan, research was conducted in collaboration with the Research Institute of Animal Husbandry and Poultry and the KOPIA Center of Korea. The feasibility of crushed feed mixing (TMR) technology was achieved through economic evaluation.

TMR feeding of livestock in combination with high-value feeds has a positive effect on the rapid growth and development of the organism, increase in live weight, productivity and product quality, as well as save labor, feed and other costs. In this technology, 6-month-old weaned calves were fattened up to 24-26 months of age (570 days).

When feeding young cattle on Korean technology, the feed was prepared in $2-3 \mathrm{~cm}$ pieces, mixed with mixed feeds, food waste from households, enriched with premixes. During the growing, maintenance and fattening periods, $1210 \mathrm{~kg}$ of mixed fodder, $1920 \mathrm{~kg}$ of natural hay, $1600 \mathrm{~kg}$ of straw and $13 \mathrm{~kg}$ of salt are used. (Table 1). For feeds during the growing season (200 days) when calculated at current prices

961.8 thousand soums (Table 2), during the maintenance period (220 days) 1850.64 thousand soums (Table 3) and during the fattening period (150 days) 1791.33 thousand soums were spent.

Table 1. Feed consumption per 1 head of cattle during breeding, maintenance and fattening periods, kg.

\begin{tabular}{|c|c|c|c|c|c|c|c|c|c|}
\hline \multirow{3}{*}{ Types of feed } & \multirow{2}{*}{\multicolumn{2}{|c|}{$\begin{array}{c}\text { Feeding During } \\
\text { The Growing } \\
\text { Season (200 } \\
\text { Days) }\end{array}$}} & \multirow{2}{*}{\multicolumn{2}{|c|}{$\begin{array}{c}\text { Feeding Costs } \\
\text { During The } \\
\text { Maintenance } \\
\text { Period (220 Days) }\end{array}$}} & \multicolumn{4}{|c|}{$\begin{array}{c}\text { Feed Consumption During The } \\
\text { Fattening Period }\end{array}$} & \multirow{3}{*}{ All } \\
\hline & & & & & \multicolumn{2}{|c|}{$\begin{array}{l}\text { Main Part (90 } \\
\text { Days) }\end{array}$} & \multicolumn{2}{|c|}{$\begin{array}{c}\text { Final Part (60 } \\
\text { Days) }\end{array}$} & \\
\hline & $\begin{array}{l}\text { In A } \\
\text { Day }\end{array}$ & Total & $\begin{array}{l}\text { In A } \\
\text { Day }\end{array}$ & Total & $\begin{array}{l}\text { In A } \\
\text { Day }\end{array}$ & Total & $\begin{array}{l}\text { In A } \\
\text { Day }\end{array}$ & Total & \\
\hline Omixta em, kg & 1 & 200 & 2 & 440 & 3 & 270 & 5 & 300 & 1210 \\
\hline Pichan, kg & 2,5 & 500 & 4 & 880 & 4 & 360 & 3 & 180 & 1920 \\
\hline Somon, kg & 2 & 400 & 3 & 660 & 4 & 360 & 3 & 180 & 1600 \\
\hline Salt, kg & 0,015 & 3 & 0,02 & 4,4 & 0,035 & 3,15 & 0,04 & 2,4 & 12,95 \\
\hline
\end{tabular}

Table 2. Feeding costs during the growing season

\begin{tabular}{|c|l|c|c|c|}
\hline № & \multicolumn{1}{|c|}{ Types of feed } & Types of feed & Types of feed & Types of feed \\
\hline 1 & Omixta em & 200 & 2000 & 400000 \\
\hline 2 & Pichan & 500 & 800 & 400000 \\
\hline 3 & Somon & 400 & 400 & 160000 \\
\hline 4 & Salt & 3 & 600 & 1800 \\
\hline & Total & & & $\mathbf{9 6 1 8 0 0}$ \\
\hline
\end{tabular}


EPRA International Journal of Agriculture and Rural Economic Research (ARER)- Peer-Reviewed Journal Volume: 10 | Issue: 3| March2022 | Journal DOI: 10.36713/epra0813| Impact Factor SJIF (2021) : 7.604| ISSN: 2321 - 7847

Table 3.Feeding costs during the maintenance period

\begin{tabular}{|c|c|c|c|c|}
\hline № & Types of feed & Amount of feed, kg & Price in soums / kg & $\begin{array}{c}\text { Total feed costs, } \\
\text { UZS }\end{array}$ \\
\hline 1 & Omixta em & 440 & 2000 & 880000 \\
\hline 2 & Pichan & 880 & 800 & 704000 \\
\hline 3 & Somon & 660 & 400 & 264000 \\
\hline 4 & Salt & 4,4 & 600 & 2640 \\
\hline & total & & $\mathbf{1 8 5 0 6 4 0}$ \\
\hline
\end{tabular}

Table 4. Feeding costs during the fattening period

\begin{tabular}{|c|c|c|c|c|}
\hline № & Types of feed & Amount of feed, $\mathbf{k g}$ & Price in soums / kg & $\begin{array}{c}\text { Total feed costs, } \\
\text { UZS }\end{array}$ \\
\hline 1 & Omixta em & 570 & 2000 & 1140000 \\
\hline 2 & Pichan & 540 & 800 & 432000 \\
\hline 3 & Somon & 540 & 400 & 216000 \\
\hline 4 & Salt & 5,55 & 600 & 3330 \\
\hline & total & & $\mathbf{1 7 9 1 3 3 0}$ \\
\hline
\end{tabular}

Table 5.Feeding costs, soums

\begin{tabular}{|c|c|c|c|}
\hline № & Periods & Term & Feeding Costs \\
\hline 1 & Grow & 200 & 961800 \\
\hline 2 & Care & 220 & 1850640 \\
\hline 3 & Fattening & 150 & 1791330 \\
\hline & total & & $\mathbf{4 6 0 3 7 7 0}$ \\
\hline
\end{tabular}

When raising bulls for meat, their live weight is one of the key indicators. The analysis of their live weight plays an important role in determining the cost of meat production, as well as the efficiency of their cultivation.

Table 6. Meat productivity of cattle in the Republic of Karakalpakstan and regions, kg.

\begin{tabular}{|l|c|c|c|c|}
\hline \multirow{2}{*}{ Provinces } & \multicolumn{2}{c|}{ Live weight } & \multirow{2}{*}{ Extra weight gain } & \multirow{2}{*}{ Daily weight gain } \\
\cline { 2 - 3 } & $\mathbf{6 ~ о и ̆ л и к ~}$ & $\mathbf{2 5}$ ойлик & \multirow{2}{*}{0,584} \\
\hline $\begin{array}{l}\text { The Republic of } \\
\text { Karakalpakstan }\end{array}$ & 78,0 & 411,1 & 333,1 & 0,621 \\
\hline Andijon & 93,9 & 447,6 & 353,7 & 0,648 \\
\hline Bukhara & 83,8 & 453,1 & 369,3 & 0,622 \\
\hline Jizzax & 85,3 & 440,1 & 354,8 & 0,653 \\
\hline Qashqadaryo & 81,4 & 453,5 & 372,1 & 0,579 \\
\hline Navoi & 86,0 & 415,8 & 329,8 & 0,566 \\
\hline Namangan & 83,5 & 406,2 & 322,8 & 0,618 \\
\hline Samarkand & 83,4 & 435,5 & 352,1 & 0,632 \\
\hline Surxondaryo & 87,6 & 448,0 & 360,4 & 0,573 \\
\hline Sirdaryo & 84,3 & 410,9 & 326,6 & 0,585 \\
\hline Tashkent & 84,2 & 417,7 & 333,5 & 0,645 \\
\hline Fergana & 86,3 & 454,2 & 367,9 & 0,582 \\
\hline Khorezm & 83,3 & 415,0 & 331,7 & $\mathbf{0 , 6 0 8}$ \\
\hline \multicolumn{1}{|c|}{ Average } & $\mathbf{4 4 , 7}$ & $\mathbf{4 3 1 , 4}$ & $\mathbf{3 4 6 , 7}$ & \\
\hline
\end{tabular}

The results show that during the growth, care, and fattening of bulls, the live weight of bulls was $71.4 \mathrm{~kg}(431.4-360)$ higher than that of conventional grazing of domestic cattle in households using Korean technology. The average live weight of 6month-old cattle purchased in the country was 84.7 $\mathrm{kg}$. As a result of 570 days of grazing, the live weight of 25-month-old cattle averaged $431.4 \mathrm{~kg}$. The average daily weight gain was 608 grams, with the highest rates in Kashkadarya, Bukhara and Fergana regions, and the lowest in Namangan region.

Meat productivity of bulls after the period of their breeding and fattening was studied and compared on the basis of indicators such as preslaughter live weight, meat and fat consumption, byproducts and internal organs consumption, morphological composition of semen on individual natural anatomical parts.

According to the results of a control bull slaughter, the live weight of the bulls in all groups

(c) 2022 EPRA ARER | www.eprajournals.com | Journal DOI URL: https://doi.org/10.36713/epra0813 
was high. This figure, pre-slaughter live weight, averaged $431.4 \mathrm{~kg}$ in the Korean technology group and $360 \mathrm{~kg}$ in the local group. That is, accordingly, the Korean technology group was $19.8 \%$ higher than the local group. It is known that in determining the meat yield of animals, slaughter expenditure is one of the main indicators. Slaughter expenditure, on the other hand, depends on the animal's levels of obesity. Nutritional norms are important in bringing animals to high levels of obesity and increasing slaughter expenditure. In a study by the Livestock Research
Institute, high slaughter rates were observed in both groups. In other words, in the group fed with Korean technology, the slaughter expenditure was $58.0 \%$, while in the group fed with local technology, it was $56.2 \%$. The Korean technology-fed group had a $1.8 \%$ higher rate than the local technology-fed group. The half-weight was $250.2 \mathrm{~kg}$ in the Korean technology group, compared to $202.3 \mathrm{~kg}$ in the local technologyfed group, or $23.7 \%$ higher than the half-weight group fed with local technology.

Table 7. Results of bull control slaughter in the experiment

\begin{tabular}{|l|c|c|}
\hline \multicolumn{1}{|c|}{ Indicators } & \multicolumn{2}{|c|}{ Groups } \\
\cline { 2 - 3 } & Korea & 360 \\
\hline Slaughter received live weight, $\mathrm{kg}$ & 431,4 & 202.3 \\
\hline Slaughter weight, kg & 250,2 & 56,2 \\
\hline Slaughter expenses, $\%$ & 58 & \\
\hline
\end{tabular}

Table 8. Income from 1 head of cattle

\begin{tabular}{|c|c|c|c|c|c|c|}
\hline \multirow{2}{*}{ Indicators } & \multicolumn{2}{|c|}{ Quantity, kg } & \multicolumn{2}{c|}{ Price, m.soum / kg } & \multicolumn{2}{c|}{ Value, m.sum } \\
\cline { 2 - 7 } & $\begin{array}{c}\text { TMR } \\
\text { technology }\end{array}$ & $\begin{array}{c}\text { Local } \\
\text { technology }\end{array}$ & $\begin{array}{c}\text { TMR } \\
\text { technology }\end{array}$ & $\begin{array}{c}\text { Local } \\
\text { technology }\end{array}$ & $\begin{array}{c}\text { TMR } \\
\text { technology }\end{array}$ & $\begin{array}{c}\text { Local } \\
\text { technology }\end{array}$ \\
\hline Meat & 250,2 & 202,3 & 54 & 50 & 13510,8 & 10115 \\
\hline Teri & & & & & 150 & 150 \\
\hline Kalla- pochcha & & & & & 800 & 200 \\
\hline Manure & & & & & $\mathbf{1 4 6 6 0 , 8}$ & $\mathbf{1 1 2 6 5}$ \\
\hline total & & & & & & \\
\hline
\end{tabular}

Table 9. Production Costs, Thousand Soums

\begin{tabular}{|l|l|c|c|}
\hline \multirow{2}{*}{$\mathbf{1}$ - Indicators } & \multicolumn{1}{|c|}{ For 1 head } & $\begin{array}{c}\text { At 19 months for 15 } \\
\text { heads }\end{array}$ \\
\hline 1 & Salary expenses & 100 & 28500 \\
\hline 2 & Feeding costs & $\mathbf{4 6 0 3 , 8}$ & 69056,6 \\
\hline 2 & Veterinary costs & 80 & 1200 \\
\hline 3 & Electricity costs & & 1121 \\
\hline 4 & Transportation costs & & 1000 \\
\hline & total & & $\mathbf{1 0 0 8 7 7 , 6}$ \\
\hline
\end{tabular}

Salary costs are 1,500,000 soums per month for 15 head of cattle and 28,500,000 soums for 19 months.

One head of cattle is vaccinated twice a year, 1 drug costs 20 thousand soums and costs 80 thousand soums in two years.

The cost of $1 \mathrm{~kW}$ of electricity is 295 soums. $200 \mathrm{kWh}$ of electricity will be consumed in 1 month, $3800 \mathrm{kWh}$ in 19 months and 1121 thousand soums will be spent.

Transportation costs associated with the transportation and sale of food products amount to 500,000 soums per year.

6-month-old calves were purchased for an average of 2,400,000 soums, while 36,000 soums were spent for 15 heads. For the preparation of fodder for cattle in the form of crushed and mixed fodder was purchased for 400 thousand soums (hay grinder) and for 100 thousand soums for each head of cattle (1500 thousand soums for 15 heads). As a result, the total cost of 15 head of cattle on TMR technology amounted to 138777.6 thousand soums, and on local technology - 136877.6 thousand soums.

The cost of one head of cattle fed on TMR technology amounted to 14660.8 thousand soums, and on local technology - 11265 thousand soums. The cost of products from 15 head of cattle in terms of technology was 219912 thousand soums and 168975 thousand soums, respectively. 
Table 10. (TMR) Technology Economic Evaluation Indicators

\begin{tabular}{|c|l|l|c|c|}
\hline \multirow{2}{*}{ № } & \multicolumn{1}{|c|}{ Indicators } & \multicolumn{1}{c|}{$\begin{array}{c}\text { Unit of } \\
\text { measurement }\end{array}$} & \multicolumn{2}{|c|}{ Technology } \\
\cline { 3 - 5 } & & TMR & \multicolumn{2}{c|}{ Local } \\
\hline 1 & Income & m.so'm & 219912,0 & 168975,0 \\
\hline 2 & Total costs & m.so'm & 138777,6 & 136877,6 \\
\hline 3 & Benefits & m.so'm & 81134,5 & 32097,5 \\
\hline 4 & Economic efficiency & m.so'm & 49037,0 & 23,4 \\
\hline 5 & The level of profitability & \multicolumn{1}{|c}{$\%$} & 58,5 & \\
\hline
\end{tabular}

\section{CONCLUSIONS}

In the development of animal husbandry, the profitability of the Korean state due to the use of bull feeding and fattening (TMR) technology was 2.5 times higher than that of domestic feeding technology. In conclusion, it should be noted that the introduction of TMR technology will improve the quality of meat, and in the future in our country will be launched the production of quality marble meat products.

\section{BIBLIOGRAPHY}

1. Nurmatov A.A., Allashov B.D., Dzhabborov S., Rustamova I., Tursunov Sh. (2020). Feeding farm animals based on the new innovative Total Mixed Ration (TMR) technology. In IOP Conference Series: Earth and Environmental Sciences (volume 614). IOP Publishing Ltd. https://doi.org/10.1088/17551315/614/1/012161

2. D.N.Saidova, I.B.Rustamova, Sh.A.Tursunov. Agrarian policy and food security. study guide. - Tashkent: The main library of the Academy of Sciences of the Republic of Uzbekistan, 2016.

3. Allayarov, S. A. (2020). Factor investigation of tax discipline for financial security. ACADEMICIA: An International Multidisciplinary Research Journal, 10(11), 2332-2337. https://doi.org/10.5958/22497137.2020.01605.5

4. Allayarov, S. A. (2020). The improvement of tax control in order to strengthen tax discipline in the republic of Uzbekistan.TRANS Asian Journal of Marketing \& Management Research (TAJMMR), 9(11),57-62.

https://doi.org/10.5958/22790667.2020.00061.9

5. Shaulska, L., Kovalenko, S., Allayarov, S., Sydorenko, O., \& Sukhanova, A. (2021). Strategic enterprise competitiveness management under global challenges. Academy of Strategic Management Journal, 20(4), 1-7.

6. Shamborovskyi, G., Shelukhin, M., Allayarov, S., Khaustova, Y., \& Breus, S. (2020). Efficiency of functioning and development of exhibition activity in international entrepreneurship. Academy of Entrepreneurship Journal, 26(Special Issue 4), 1-7.

7. Disler, R. T., Gallagher, R. D., Davidson, P. M., Sun, S.-W., Chen, L.-C., Zhou, M., Mistraletti, G. (2019). Factors impairing the postural balance in COPD patients and its influence upon activities of daily living. European Respiratory Journal, 15(1), 142-148.

8. Raigar, R. K., Mishra, H. N., Dobhal, N., Raghuvanshi, R. S., Arelovich, H. M., Lagrange, S., ... Ezeikpe, D. O. (2017). Effect of raw or roasted whole soybeans on early lactational performance and ruminal and blood metabolites in Iranian cows. Journal of Dairy Science, 37(1), 529-537.

9. Durmanov, A., Kalinin, N., Drobyazko, S., Yanishevska, K., Shapovalova, I. (2019). Strategic support of innovative activity of modern enterprises. 34th IBIMA Conference: 13-14 November 2019, Spain

10. Atakhanova N., Almuradova D., Khakimov G., Usmonova S., \& Durmanov A. (2020). Values of a mathematical model for predicting the survival of patients with triple negative breast cancer depending on androgen receptors. International Journal of Pharmaceutical Research, 12(3), 695-704. https://doi.org/10.31838/ijpr/2020.12.03.104

11. Durmanov, A., Kalinin N., Stoyka, A., Yanishevska, K., \& Shapovalova, I. (2020). Features of application of innovative development strategies in international enterprise. International Journal of Entrepreneurship Issues, 1(24), 1-9.

12. Aliev Y.E., Kasimov, S.S., Ruzieva, D.I., Nigmatullaeva G.N., Abdurakhmanov P.M. Durmanov A.S. (2020). Agriculture provides sustainability issues of agricultural market development. International Journal of Psychosocial Rehabilitation, 24 (8), 7508-7529. https://doi:10.37200/ijpr/v24i8/pr280764

13. Ubaydillayev A.N., Kholmuratova G.M., Umarov S.R., Muradov R.A., Durmanov A.S. (2020). Heat and Energy-Economic Analysis for Greenhouses of the Republic of Uzbekistan. International Journal of Advanced Science and Technology Vol. 29, No. 8, (2020), pp.32853298

14. Durmanov, A., Bayjanov, S., Khodjimukhamedova, S., Nurimbetov, T., Eshev, A., Shanasirova, N. (2020). Issues of accounting for organizational and economic mechanisms in greenhouse activities. Journal of Advanced Research in Dynamical and Control Systems, Vol. 12, No 07-Special Issue pp. 114126 doi: 10.5373/jardcs/v12sp7/20202089

15. Дурманов А.Ш. Инновачионные технологии $и$ методы обучения в профессиональные образования. "Фан, таълим ва ишлаб чиқариш интеграчиясини ахборот коммуникация технологиялари 
асосида ривожлантириш муаммолари" Республика илмий-амалий анжуман материаллари туиллами. Қарии, 2012, 97-99 $\mathrm{cm}$.

16. Дурманов А.Ш. “Формирование инновачионной стратегии аутсорсинга”. "Иқтисодиётни м модернизачиялаш шароитида хизмат кўрсатиш сохаси самарадорлигини ошириш ва инноваџион фаолиятни такомилламтирим муаммолари" мавзусидаги республика анъанавий илмий-амалий конференция. Самарқзанд-2014, 219-221 cm

17. Дурманов А.Ш. «Развитие предпринимательства и соииального партнерства в Узбекистане». "Ижтимоий хамкорлик-иқтисодий муносабатларни эркинлаштириш омили» мавзусидаги илмийамалий конференция, Тошкент-2014, 135$138 \mathrm{~cm}$.

18. Дурманов А.Ш. «Инвестиционная политика $u$ ее реализация в сельскомхозяйстве Республики Узбекистан».

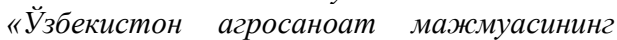
рақ̧обат бардошлигини ошириш ва экспорт салохиятини юксалтириш» мавзусидаги республика анъанавий илмий-амалий конференция, Тошкент-2014, 271-274 cm.

19. Durmanov A. Sh. Cooperation as a basis for increasing the economic efficiency of production of open ground vegetables. «Бюллетень науки и практики» 2018 г. 9

20. Durmanov A. Sh. Foreign experience the organizational-economic mechanisms of improving the activities of greenhouse farms. Economics and Finance. 2018. 7

21. Бельй В.С. История гарнизона Васьково. В книге: Арутюнова Г.И., Атаев 3. В., Белый В.С., Братков В.В., Галаутдинова В.В., Григорьева Т.М., Дурманов А.Ш., Железная А.Б., Кудина М.В., Ла-пина С.Б., Ли М.Р., Мельников С.В., Минаков А.В., Мыльникова Е.М., Нагибина Н.П., Рудюк М.Ю., Тулабоев А.К., Холуденева А.О., Чекайкин С.В., Черновалова Г.А. $u$ др. Интеллектуальный капитал $и$ инновационное развитие экономики, науки и об-разования. Монография. Пенза, 2019. С. 99-119.

22. Toxirov A., Durmanov A. The development of the education and training system, innovative management and organizational factors // Наука и современное общество: взаимодействие и развитие. - Уфа: Ника, 2015. - No 1 (2). - C. 87-89.

23. Umurzakov, U., Ibragimov, A., \& Durmanov, A. (2017). Development of organizationaleconomic mechanism and development of scientific-methodical and theoretical bases of increase of efficiency of the industry of rice cultivation to ensure food security of the country. Bulletin of Science and Practice, (11), 103-118 doi:10.5281/zenodo.1048318

24. Umurzakov U.P., Ibragimov A.G. And Durmanov A.Sh. Factors of Stability of Development of Regional Agricultural Rice
Production. International Journal of Management, IT \& Engineering. November s2017 Volume-7, Issue-11. - 4-6 p. 